\title{
Bimbingan Agama Melalui Teknik Clien Centred dalam Pembentukan Kepribadian Remaja
}

\author{
Sri Mulyani ${ }^{*}$, Sachri Ramdhan ${ }^{2}$, Dadang Ahmad Fajar ${ }^{1}$ \\ ${ }^{1}$ Jurusan Bimbingan dan Konseling Islam, UIN Sunan Gunung Djati, Bandung \\ ${ }^{2}$ Jurusan Komunikasi Penyiaran Islam UIN Sunan Gunung Djati, Bandung \\ *Email: srimulyaniefendii@gmail.com
}

\begin{abstract}
ABSTRAK
Penelitian ini bertujuan untuk mengetahui program, proses, dan hasil bimbingan agama melalui teknik client centred dalam pembentukan kepribadian remaja di kelas IX. Metode yang digunakan dalam penelitian ini adalah metode deskriptif dengan pendekatan kualitatif, dengan teknik observasi, wawancara dan angket. Bimbingan agama melalui teknik clien centred dilaksanakan melalui Pembelajaran Rumpun PAI, pembiasaan melalui Shalat Dhuha berjamaah, Kuliah tujuh menit, dan ekstrakurikurer Baca dan Tulis Al-Quran (BTQ) yang dilaksanakan setiap hari dan satu minggu sekali, sesuai dengan jadwal yang ditetapkan. Hasil penelitian menunjukkan bahwa siswa kelas IX MTS As-Solehhyiah memiliki kepribadian Islami pada kategori tinggi.
\end{abstract}

Kata Kunci: Bimbingan Agama; Teknik Client Centred; Kepribadian Remaja.

\begin{abstract}
This study aims to determine the program, process, and results of religious guidance through client-centered techniques in shaping the personality of adolescents in class IX. The method used in this research is descriptive method with a qualitative approach, with observation, interview and questionnaire techniques. Religious guidance through clien centered techniques is carried out through P AI Cluster Learning, habituation through Dhub a Prayers in congregation, a sevenminute lecture, and Al-Quran Reading and Writing (BTQ) extracurricular activities which are beld every day and once a week, according to the specified schedule. The results showed that the students of class IX MTS As-Solebhyiah had an Islamic personality in the high category.
\end{abstract}

Keywords: Religious Guidance, Client Centred Technique, Teenage Personality. 
S, Mulyani., S. Ramdhan., D.A. Fajar.

\section{PENDAHULUAN}

Remaja merupakan seseorang yang sedang mencari jati diri, biasanya banyak di usia remaja ini yang mulai tidak dekat dengan orang tuanya, mulai mempercayai orang lain atau kerabat dekat dibandingkan dengan orang tuanya. Bila anak usia remaja salah mempercayai orang, maka akan salah juga segala pemahaman dan konsep yang ada dalam dirinya. Padahal, bila diibaratkan usia remaja ini adalah sebuah tunas. Bila tunas itu baik merawatnya, maka akan baik pula tunas bertumbuhnya tunas tersebut. Sama dengan remaja, bila seorang remaja sudah mencari atau menanamkan sebuah konsep atau pemahaman yang baik untuk dirinya, maka akan baik pula pemahaman remaja tersebut (Satriah, 2017:163).

Dalam masa perkembangannya, remaja menggalami banyak masalah dalam penyesuaian diri dibandingkan dengan masa sebelumnya karena ternyata pada masa anak-anak cukup tenang dan bahagia. Dalam masa pertumbuhannya dia mengalami ketegangan batin akibat ingin lepas dari ketergantungan dan pengawasan orang dewasa (Djali, 2013: 58).

Permasalahan yang kerap terjadi di kalangan remaja tersebut timbul karena adanya sebuah penyimpangan kepribadian yang yang yang menjadi perhatian setiap orang dimana saja. Kerusakan moral seseorang merupakan ciri dari kepribadian buruk orang tersebut dan dapat mengganggu ketentraman yang lain. Apabila ditinjau dari keadaan masyarakat yang ada di Indonesia terutama di kotakota besar pada saat ini tentu akan didapati sebagian anggota masyarakat yang berkepribadian buruk, kepentingan umum tidak lagi menjadi hal yang utama melainkan kepentingan pribadi yang menjadi sesuatu hal yang paling utama.

Kepribadian tumbuh seiring dengan perkembangan tubuh dan jiwa seseorang sesuai dengan perkembangan di tempat Ia berada. Kepribadian erat kaitannya dengan bagaimana Ia dididik oleh orangtua, lingkungan bergaul dan terutama lingkungan keluarga, membina kepribadian anak bukan sekedar memberi sandang dan pangan, akan tetapi yang lebih penting menanamkan bekal agama dan membina kepribadian anak.

Kondisi objektif siswa MTs Satu Atap As-Solehhiyah Kelas IX yang dikategorikan memiliki kepribadian yang buruk disebabkan berbagai faktor yang timbul dari luar sekolah. Faktor tersebut berasal dari faktor keluarga, faktor teman sebaya, dan faktor lingkunga. Ketiga faktor tersebut dibawa ke lingkungan sekolah tempat mereka beradaptasi bersama dengan teman sebayanya di sekolah.

Adapun bimbingan agama yang dilakukan di MTs Satu Atap As-Solehhiyah ini yaitu bimbingan agama melalui Shalat Dhuha berjamaah yang bertujuan untuk membentuk spiritual siswa dengan membiasakan ibadah sunah yang di harapkan membentuk kepribadian Islami siswa, kultum dan shalawat yang bertujuan untuk 
Bimbingan Agama Melalui Teknik Clien Centred dalam Pembentukan Kepribadian Remaja membiasakan siswa terbiasa berbicara di depan umum dan melatih keberanian untuk tampil di depan umum. Bimbingan agama melalui pembelajaran rumpun PAI memiliki tujuan khusus pendidikan agama Islam yaitu terkait dengan pengembangan rasa cinta kepada agama dan akhlak, serta Ekstrakurikurer Baca Tulis Al-Quran ( BTQ ) yang dilakukan bertujuan agar siswa senantiasa membaca Al-Quran dan menjadikan siswa tidak sekedar tahu bacaannya saja, tetapi menjadikan siswa untuk mengerti isi kandungan yang terdapat dalam Al-Quran.

Berdasarkan latar belakang masalah di atas, maka yang menjadi permasalahan dalam penelitian ini adalah program, proses dan hasil bimbingan agama yang dilaksanakan dalam upaya membentuk kepribadian remaja di MTs AsSolehhiyah Satu Atap melalui teknik client centred.

Penelitian ini dilaksanakan di salah satu lembaga pendidikan yaitu di Yayasan Pendidikan MTs SA As-Solehhiyah di Kp. Haur Hapit Rt. 01/14 Ds. Bojongsari Kec. Bojongsoang Kabupaten Bandung. Metode yang digunakan dalam penelitian ini yaitu deskriptif kualitatif. Penelitian kualitatif dilakukan untuk menghasilkan data deskriptif'. Penelitian Kualitatif merupakan penelitian yang menghasilkan prosedur data deskriptif yang berupa kata-kata tertulis atau lisan dari orang dan perilaku yang dapat diamati” (Moeleong J. Lexy, 2005:4).

Jenis penelitian ini adalah penelitian kualitatif, yaitu penelitian yang memiliki karakteristik, bahwa dasarnya menyatakan dalam keadaan sebenarnya atau sebagaimana adanya (natural setting) dengan tidak mengubah dalam bentuk simbolsimbol atau bilangan. Maka penelitian kualitatif adalah penelitian yang menghasilkan prosedur analisis data deskriptif yang bermaksud untuk memahami fenomena yang diteliti secara terinci, mendalam dan menyeluruh dari hasil lapangan. Adapun pendekatan yang digunakan yakni pendekatan fenomenologis yakni pendekatan yang berusaha memahami arti peristiwa dan kaitan-kaitannya terhadap orang-orang biasa dalam situasi-situasi tertentu. Istilah "fenomenologis" sering digunakan sebagai anggapan umum untuk menunjuk pada pengalaman subjektik dari berbagai jenis dan tipe subjek yang ditemui.

Data yang dibutuhkan dalam penelitian ini terbagi dalam sumber data primer merupakan data yang diperoleh langsung dari sumbernya, diamati dan dicatat untuk pertama kalinya. Adapun sumber data primer dalam penelitian ini adalah responden (orang yang dapat merespon) tentang data penelitian yang disebut dengan konselor, dan dilakukan wawancara langsung dengan subjek penelitian. Sedangkan sumber data sekunder adalah data yang diperoleh dari sumber pendukung untuk memperjelas sumber data primer baik berupa data kepustakaan yang berkorelasi dengan pembahasan objek penelitian termasuk dokumentasi, maupun sumber-sumber relevan. 
S, Mulyani., S. Ramdhan., D.A. Fajar.

\section{LANDASAN TEORITIS}

Menurut Chodijah (2016: 133) "Bimbingan dan konseling merupakan salah satu pilar untuk mengatasi akhlak baik dan buruk dan meningkatkan akhlak yang baik". Sedangkan menurut Faqih (2004:62)," Bimbingan agama adalah proses pemberian bantuan terhadap individu agar dalam kehidupan keagamaan senantiasa selaras dengan ketentuan dan petunjuk Allah, sehingga dapat mencapai kebahagiaan hidup di dunia dan diakhirat".

Tujuan dari bimbingan keagamaan adalah untuk membantu individu ataupun kelompok individu mencegah timbulnya masalah-masalah dalam kehidupan keagamaan antara lain dengan cara membantu individu menyadari fitrah manusia, membantu individu mengembangkan fitrahnya, membantu individu memahami dan menghayati ketentuan dan petunjuk Allah dalam kehidupan keagamaan serta membantu individu menjalankan ketentuan dan petunjuk Allah mengenai kehidupan keagamaan.

Fungsi dari bimbingan agama adalah sebagai berikut: (1) Fungsi preventif, yakni membantu individu menjaga atau mencegah timbulnya masalah bagi dirinya, (2) Fungsi kuratif atau korektif, yakni membantu individu memecahkan masalah yang sedang dihadapi atau dialaminya, (3) Fungsi preservatif, yakni membantu individu menjaga agar situasi dan kondisi yang semula tidak baik (mengandung masalah) menjadi baik (terpecahkan) dan kebaikan itu bertahan lama (in state of good), (4) Fungsi developmental atau pengembangan, yakni membantu individu memelihara dan mengembangkan situasi dan kondisi yang telah baik agar tetap baik atau menjadi lebih baik, sehingga tidak memungkinkannya menjadi sebab munculnya masalah baginya (Aunur Rahim faqih 2004:37).

Asas-asas bimbingan agama diantaranya: (1) Asas fitrah, fitrah merupakan titik tolak utama bimbingan dan keagamaan, karena konsep fitrah itu ketauhidan yang asli. Artinya manusia pada dasarnya telah membawa fitrah (naluri beragama yang mengesakan Allah), sehingga bimbingan keagamaan harus senantiasa mengajak kembali manusia memahami dan menghayatinya, (2) Asas kebahagiaan dunia dan akhirat, jika manusia telah mampu memahami dan menghayati fitrahnya maka itu harus terus dibina dan dikembangkan dalam rangka mencapai kebahagiaan dunia dan akhirat.

Sebuah teknik yang efektif dapat menunjang terhadap keberhasilan dalam proses bimbingan, oleh sebab itu memungkinkan untuk dianalisis pengaruhnya dengan pengalaman yang dilakukan oleh klien. Adapun bentuk teknik yang digunakan dalam bimbingan agama diantaranya adalah teknik client centred dan eductive method 'metode pencerahan'

Teknik client centred merupakan model terapi yang berpusat pribadi yang di 
Bimbingan Agama Melalui Teknik Clien Centred dalam Pembentukan Kepribadian Remaja

kembangkan oleh Carl R. Rogers. Carl R. Rogers mengembangkan terapi client centred sebagai reaksi terhadap apa yang disebutnya keterbatasan-keterbatasan mendasar dari psikoanalisis. Pada hakikatnya, pendekatan client centred adalah cabang khusus dari terapi humanistik yang menggaris bawahi tindakan mengalami klien berikut dunia subyektif dan fenomenalnya (Gerald, 2013:91).

Teknik client centred sering disebut juga disebut nondirective 'tidak mengarahkan'. Dalam teknik ini terdapat dasar pandangan bahwa klien sebagai makhluk bulat yang memiliki kemampuan berkembang sendiri dan sebagai pencari kemantapan diri sendiri (self consistency). Dalam bimbingan agama Surya (2013:72) mengemukakan bahwa:

Terdapat eductive method (metode pencerahan), metode ini sebenranya hampir sama dengan teknik client centred akan tetapi bedanya terletak pada usaha mengorek sumber perasaan yang menjadi beban tekanan batin klien serta mengaktifkan kekuatan/tenaga kejiwaan klien (potensi dinamis) melalui pengertian tentang realitas situasi yang dialami olehnya. Oleh karena itu, inti dari metode ini adalah pemberian "insight" dan klasifikasi (pencerahan) terhadap unsur-unsur kejiwaan yang menjadi sumber konflik seseorang.

Kepribadian yaitu keseluruhan pola (bentuk) tingkah laku, sifat-sifat, kebiasaan, kecakapan bentuk tubuh serta unsur-unsur psiko-fisik lainnya yang selalu menampakkan diri dalam kehidupan seseorang (Ahmad, 2005:158).

Dengan kata lain dapat dikatakan kepribadian yang mencakup semua aktualisasi dari (penampilan) yang selalu tampak pada diri seseorang, merupakan bagian yang khas atau ciri dari seseorang. Setiap orang memiliki kepribadian yang berbeda, namun dalam beberapa hal mungkin memiliki persamaan. Orang yang berasal dari satu keluarga biasanya memiliki persamaan dalam kepribadiannya, demikian pula dengan orang yang satu suku atau satu ras akan memiliki persamaan dalam kepribadian. Dengan kata lain, setiap keluarga, suku atau bangsa memiliki ciri-ciri khas dari kepribadiannya yang dapat membedakan mereka dari suku atau bangsa lainnya.

Menurut Arisatul Maulana dan Hernisawati (2015: 57) kepribadian merupakan ciri, karakteristik, atau sifat khas diri seseorang yang bersumber dari bentukan-bentukan yang diterima dari lingkungan, misalnya keluarga pada masa kecil dan bawaan sejak lahir.

Kepribadian seseorang adakalanya menarik hati orang lain tetap adakalanya tercela. Kepribadian yang menarik adalah yang memiliki unsur-unsur positif seperti raji, penyabar, pemurah, pemarah, suka menolong, pembersih dan sebagainya. Sedangkan kepribadian yang tercela misalnya pemalas, pemarah, kikir, sombong, angkuh, penjorok dan sebagainya. 
S, Mulyani., S. Ramdhan., D.A. Fajar.

Aspek-aspek kepribadian, para ahli psikologi memberikan penekanan bahwa yang dipelajari oleh psikologi bukanlah jiwa, tetapi tingkah laku manusia baik perilaku yang kelihatan (overt) maupun yang tidak kelihatan (covert). Tingkah laku manusi dianalisis ke dalam tiga aspek atau fungsi, yaitu: 1) Aspek kognitif (pengenalan), yaitu pemikiran, ingatan, hayalan, daya bayangan, inisiatif, kreativitas, pengamatan, dan pengindraan. Fungsi aspek kognitif adalah menunjukkan jalan, mengarahkan, dan mengendalikan tingkah laku, 2) Aspek afektif, yaitu bagian kejiwaan yang berhubungan dengan kehidupan alam perasaan atau emosi, sedangkan hasrat, kehendak, kemauan, keinginan, kebutuhan, dorongan dan elemen motivasi lainnya disebut aspek konatif atau psiko-motorik (kecenderungan atau niat tindak) yang tidak dapat dipisahkan dengan aspek afektif. Kedua aspek itu sering disebut aspek finalis yang berfungsi sebagai energi atau tenaga mental yang menyebabkan manusia bertingkah laku, 3) Aspek motorik, yaitu berfungsi sebagai pelaksanaan tingkah laku manusia seperti perbuatan dan gerakan jasmani lainnya.

Walaupun para ahli telah menganalisis aspek-aspek tingkah laku manusia, kita harus berpegang pada pengertian manusia sebagai satu kesatuan yang utuh, yaitu manusia yang berkekehendak, berperasaan, berpikir, dan berbuat.

Permasalahan yang kerap terjadi di kalangan remaja tersebut timbul karena adanya sebuah penyimpangan kepribadian yang menjadi perhatian setiap orang dimana saja. Kerusakan moral seseorang merupakan ciri dari kepribadian buruk orang tersebut dan dapat mengganggu ketentraman yang lain. Apabila ditinjau keadaan masyarakat yang ada di Indonesia terutama di kota-kota besar pada saat ini tentu akan didapati sebagian anggota masyarakat yang berkepribadian buruk, yaitu kepentingan umum tidak lagi menjadi hal yang utama, sebaliknya kepentingan pribadi yang menjadi hal yang paling utama. oleh sebab itu, bimbingan agama Islam di perlukan untuk membantu para remaja menemukan jalan yang mudah untuk melalui lika-liku kehidupan pada saat era zaman yang seperti saat ini. Bimbingan agama merupakan proses pemberian bantuan terhadap individu agar dalam kehidupan keagamaan senantiasa selaras dengan ketentuan dan petunjuk Allah, sehingga dapat mencapai kebahagiaan hidup di dunia dan diakhirat

\section{HASIL DAN PEMBAHASAN}

Yayasan pendidikan MTs Satu Atap As-Solehhiyah didirikan pada tahun 2006 di Kp. Haurhapit Rt01/14 Desa Bojongsari Kecamatan Bojongsoang Kabupaten Bandung 40288. Pendiri dari yayasan pendidikan Mts As-Solehhiyah ini yaitu Bapak H.A.M. Saefulloh, dilatarbelakangi oleh cita-cita Beliau untuk membangun dan memperbaiki keadaan lingkungan sekitar, karena dilingkungan sekitar masyarakat masih belum mengganggap pentingnya pendidikan, oleh karena itu 
Bimbingan Agama Melalui Teknik Clien Centred dalam Pembentukan Kepribadian Remaja diharapkan dengan didirikannya sekolah ini dapat mengubah cara berfikir masyarakat agar tidak memandang pendidikan dengan sebelah mata.

Pada tahun pertama didirikannya yayasan pendidikan Mts Satu Atap AsSolehhiyah dahulunya masih bernama Al-Mukhlisin II, sekolah masih menginduk pada sekolah lain, dikarenakan jumlah siswa yang masih kurang, gedung sekolah yang belum memadai dan kurangnya tenaga pendidik. Waktu pertama kali sekolah ini berdiri hanya memiliki 3 ruang kelas dengan kepala sekolah Ibu Siti Khodijah. Pada awal berlangsungnya kegiatan belajar mengajar hanya memiliki 25 siswa dengan 10 tenaga pendidik. Pada tahun kedua didirikan, Al-Mukhlisin II ini berganti nama menjadi As-Solehhiyah.

Seiring dengan berjalannya waktu, faktor pendukung untuk menunjang dalam proses kegiatan pembelajaran dari segi pendidik, sarana prasarana dan lain sebagainya mulai berkembang. Berdasarkan surat keputusan mentri pendidikan dan kebudayaan republik Indonesia MTs Satu Atap ini memiliki izin operasional dengan No Operasional kd.10.4/04/PP.00.5/351/2010. Dan pada tanggal 23 Juni 2010. Mts As-Solehhiyah terakreditasi A dengan no SK 02.00/322/BAPSM/XI/2013. (Arsip data Madrasah, April 2018)

Visi, Misi dan Tujuan Madrasah Tsanawiyah Satu Atap As-Solehhiyah kecamatan Bojongsoang memiliki visi menjadikan lembaga pendidikan yang mampu mengembangkan seluruh potensi dan menghasilkan generasi muslim yang berkualitas disertai ketauhidan yang bersih, menguasai IPTEK dan mampu mengaktualisasikannya dalam masyarakat. Dan memiliki misi membangun dan menyelenggarakan sistem pendidikan komprehensif yang menyiapkan lulusannya untuk menjadi generasi muslim yang mampu mempunyai ketauhidan, kreatif, inovatif, pro aktif dan mampu mengaktualisasikannya dalam masyarakat.

Tujuan didirikannya MTs Satu Atap As-Solehhiyah diantaranya sebagai berikut: (a) Menjadikan lingkungan madrasah yang kondusif bagi terbentuknya siswa yang shaleh, cerdas, kreatif, dan menyenangi kegiatan belajar, (b) Mengembangkan kurikulum, fasilitas dan model pembelajran yang tepat untuk membentuk siswa yang shaleh, cerdas, kreatif dan menyenangi kegiatan belajar, ( c) Mengembangkan dan mencontohkan tingkah laku siswa yang berakhlakul karimah,(d) Mengembangkan model hubungan sekolah dengan orang tua siswa yang tepat sehingga terdapat kontinuitas dan konsistensi antara rumah dan madrasah sebagai lingkungan pembelajaran yang sesuai dengan visi lembaga, (e) Membuat dan mengembangkan model sistem seleksi, pelatihan dan pengembangan guru yang sesuai dengan sistem persekolahan yang disebutkan dalam visi dan misi lembaga. 
S, Mulyani., S. Ramdhan., D.A. Fajar.

\section{Program Bimbingan Agama Melalui Teknik Clien Centred}

Penelitian dilaksanakan pada siswa kelas IX MTs Satu Atap As-Solehhiyah Tahun Ajaran 2017/2018 sebanyak 36 orang sebagai populasi pada penelitian ini. Penelitian ini dilaksanakan pada hari Kamis tanggal 15 Maret 2018 sampai hari Kamis tanggal 22 Maret 2018. Pertimbangan dalam menentukan populasi penelitian adalah siswa yang duduk di bangku kelas IX karena siswa kelas IX berada pada fase remaja yang telah melewati masa anak, dimana siswa kelas IX berada pada rentang usia 15-16 tahun.

Bimbingan merupakan proses bantuan terhadap individu untuk mencapai pemahaman diri dan pengarahan diri yang dibutuhkan bagi penyesuaian diri secara baik dan maksimum di sekolah, keluarga dan masyarakat". Menurut Dewa Ketut Sukardi, "bahwa bimbingan adalah proses pemberian bantuan kepada seseorang atau kelompok orang secara terus menerus dan sistematik oleh guru pembimbing agar individu atau kelompok individu menjadi pribadi yang mandiri (Lilis, 2017:37).

Program bimbingan merupakan suatu rencana kegiatan atau rancangan kegiatan yang akan dilaksanakan dalam jangka waktu tertentu. Rencana atau rancangan kegiatan ini disusun secara sistematis, terorganisasi dan terkoordinasi dalam jangka waktu tertentu yang diarahkan kepada pencapaian tujuan pendidikan di lembaga yang bersangkutan. Berdasarkan pernyataan tersebut, program bimbingan keagamaan ini terdapat di MTs Atap As-Solehhiyah yaitu dengan menintegrasikan bimbingan agama dalam rumpun mata pelajaran PAI seperti mata pelajaran Aqidah akhlak, Al-quran hadits, Sejarah Kebudayaan Islam, Fiqih, dan Bahasa Arab. Selain bimbingan agama yang diintegrasikan dengan rumpun PAI, guru pembimbing di MTs Satu Atap As-Solehhiyah ini menyelenggarakan kegiatan bimbingan agama yang rutin dilaksanakan oleh para siswa siswinya, seperti: bimbingan agama melalui Shallat dhuha berjamaah, kultum dan Shallawat, ekstrakrlikuler Baca Tulis Al-Qur'an (BTQ).

Beberapa aspek yang perlu dilakukan dalam menjalankan program kegiatan bimbingan keagamaan diantaranya: (1) Visi dan Misi, (2) Deskripsi Kebutuhan; (3) Tujuan Program; (4) Jenis-jenis Program; (5) Sasaran Program; (6) Personil Pelaksana Program; dan (7) Evaluasi.

Berdasarkan hal tersebut dijelaskan rinciannya sebagai berikut: (1) Visi dan Misi program bimbingan keagamaan yaitu berdasarkan visi dan misi madrasah, yang mengacu kepada kebutuhan siswa akan adanya program bimbingan keagamaan agar terbentuknya siswa yang shaleh, cerdas, kreatif, dan menyenangi kegiatan belajar. (2) Deskripsi Kebutuhan berisi informasi tantang gambaran kondisi umum siswa, yaitu kondisi siswa di MTs Satu Atap As-Solehhiyah ini berasal dari daerah, lingkungan, kelas sosial ekonomi yang berbeda-beda agar siswa 
saling menghargai, mengenal antara siswa yang satu dengan siswa yang lainya.

Bimbingan keagamaan ini merupakan salah satu bentuk preventif yaitu agar individu menjaga atau mencegah timbunya masalah bagi dirinya serta bentuk developmental atau pengembangan agar siswa memelihara dan mengembangkan situasi dan kondisi yang telah baik agar tetap baik atau menjadi lebih baik. (3) Tujuan Program bimbingan keagamaan di MTs Satu Atap As-Solehhiyah yaitu untuk menumbuhkan keimanan kepada siswa yang diharapkan keimanannya tersebut dapat tersentuh serta untuk membentuk siswa yang shaleh, cerdas, kreatif, inovatif, pro aktif, dan mampu mengaktualisasikannya dalam masyarakat yang kemudian tujuan tersebut menjadi visi dan misi layanan bimbingan keagamaan di MTs Satu Atap As-Solehhiyah. (4) Jenis-Jenis Program dalam menentukan jenisjenis kegiatan bimbingan keagamaan yang ada di MTs Satu Atap As-Solehhiyah dibagi menjadi dua kriteria, yaitu kegiatan bimbingan keagamaan harian, dan kegiatan bimbingan keagamaan mingguan.

Rincian kegiatan bimbingan keagamaan ini yaitu sebagai berikut: (a) Bimbingan Agama Melalui Shallat Dhuha Berjamaah, (b) Kultum Dan Shallawat (c) Bimbingan Agama Yang Diintegrasikan Dengan Rumpun PAI, (d) Ekstrakrlikuler Baca Tulis Al-Qur'an (BTQ), (5) Sasaran Program adalah seluruh siswa yang mendapatkan bimbingan keagamaan. Sedangkan untuk penelitian ini sasaran programnya adalah siswa kelas IX di MTs Satu Atap As-Solehhiyah. (6) Personil Pelaksana Program dibutuhkan pihak yang terkait dalam keterlaksanaan program bimbingan keagamaan ini, perlaksanaan program adalah pembimbing keagamaan yang berkoordinasi dengan kepada sekolah, wali kelas, guru mata pelajaran. (7) Rencana Evaluasi sangat dibutuhkan bagi terlaksananya program kegiatan. Dari evaluasi tersebut dapat diketahui keberhasilan terlaksananya program dengan tujuan yang telah ditetapkan sebelumnya. Selain itu, evaluasi dapat digunakan dalam rangka perbaikan dan peningkatan program yang telah dilaksananakan.

Langkah-langkah evaluasi program bimbingan keagamaan ini terdiri dari penyusunan rencana evaluasi, pengumpulan data dan informasi, dan data yang telah ada dianalisis dan disimpulkan.

\section{Proses Bimbingan Agama Melalui Teknik Clien Centred}

Kriteria atau patokan yang dipakai untuk mengevaluasi keberhasilan pelaksanaan program bimbingan dan konseling mengacu terhadap terpenuhi atau tidaknya kebutuhan-kebutuhan siswa dan pihak-pihak yang terlibat baik secara langsung ataupun tidak langsung berperan dalam membantu siswa memperoleh perubahan perilaku ke arah yang lebih baik.

Bimbingan sebagai bagian yang tidak terpisahkan dari proses pendidikan secara keseluruhan merupakan upaya yang memungkinkan klien mengenal dan 
S, Mulyani., S. Ramdhan., D.A. Fajar.

menerima lingkungan secara positif dan dinamis, serta mampu mengambil keputusan, mengarahkan dan mewujudkan diri sendiri secara efektif, produktif sesuai dengan peran yang diinginkannya di masa depan. Merujuk pada visi dam misi di MTs Satu Atap As-Solehhiyah dalam membangun dan menyelenggarakan sistem pendidikan yang menyiapkan lulusannya untuk menjadi generasi muslim yang mampu mempunyai ketauhidan, maka bimbingan agama sangat berperan penting sebagai penunjang terealisasinya visi dan misi tersebut.

Dalam pelaksanaan bimbingaan, kriteria yang harus ada dalam diri pembimbing adalah kepribadian yang baik. Hal ini berpengaruh terhadap keberhasilan dari proses bimbingan karena pembimbing merupakan sosok yang menjadi panutan atau teladan. Kemudian sifat yang harus dimiliki diantaranya yaitu menyampaikan materi sesuai dengan permasalahan, cerdas, menjalankan tugas dengan baik dan cinta kepada kebenaran.

Sifat dasar yang diperlukan muncul dari diri pembimbing yaitu sifat nafsiyah terdiri dari semangat, terpercaya, dan mengamalkan ilmu yang dimiliknya, serta sifat ijmaiyah yaitu tentang perilaku dalam interaksi dengan orang lain seperti budi pekerti yang baik dan mengataka kebenaran (Enjang dan Mujib, 2009: 73-74)

Pelaksanaan bimbingan agama di sekolah dapat dilakukan oleh para guru agama dengan bantuan fasilitas administratif dan kepala sekolah, bimbingan agama di MTs Satu Atap As-Solehhiyah ini, guru pembimbing menintegrasikan bimbingan agama dalam rumpun mata pelajaran PAI seperti mata pelajaran Aqidah akhlak, Al-quran hadits, Sejarah Kebudayaan Islam, Fiqih, dan Bahasa Arab.

Adapun proses pelaksanaan bimbingan agama melalui teknik Clien centred yaitu sebagai berikut:

Pertama, bimbingan agama melalui shalat dhuha berjamaah. Sebelum kegiatan belajar mengajar dimulai, seluruh siswa/i diwajibkan untuk mengikuti shallat dhuha berjamaah. Pembimbing mengarahkan siswa/i untuk melaksanakan shallat dhuha agar seluruh siswa/i dapat terbiasa melaksanakan shallat dhuha. Bukan hanya siswa/i, tetapi pembimbing beserta guru memberikan contoh secara langsung terkait dengan pelaksanaan shallat dhuha ini. Para siswa laki-laki khususnya, diajarkan untuk menjadi imam pada saat shallat berjamaah. Dan para siswa laki-laki di tekankan pada setiap harinya bergantian untuk menjadi imam pada saat shallat dhuha berjamaah ini.

Kedua, kultum dan shalawat. Pada proses kultum dan shallawat dilakukan setelah pelaksanaan shallat dhuha berjamaah. Kegiatan ini dilaksanakan oleh guru pembimbing dan siwa/i MTs Satu Atap As-Solehhiyah. Tahapan kegiatan ini diantaranya: (1) Tahap Awal/PembukaPada sesi ini guru pembimbing 
Bimbingan Agama Melalui Teknik Clien Centred dalam Pembentukan Kepribadian Remaja mengucapkan salam sebelum acara dimulai, kemudian menyampaikan muqodimah, dan membuka acara dengan mengucapkan basmalah. Shallawat. Yaitu pembacaan shallawat yang dilakukan oleh salah satu siswa yang ditunjuk oleh guru pembimbing.( 2) Tahap Pertengahan, diantaranya: Kultum. Pada sesi ini salah satu siswa/i diberikan kesempatan untuk menyampaikan ilmu yang telah didapat disekolah sebagai praktek dari hasil belajar yang telah didapat. Materi. Pada sesi ini guru pembimbing memberikan materi berdasarkan tema kultum yang yang telah disampaikan oleh siswa. Tanya/jawab. Pada sesi ini, siswa/i boleh bertanya tentang materi yang telah disampaikan dengan teknik mengajukan pertanyaan dan guru pembimbing langsung menjawab. (3) Tahap Akhir, yaitu penutup: Kegiatan bimbingan ditutup dengan membaca do'a penutup dan guru pembimbing mengucapkan Salam. (Hasil wawancara dengan Ibu Ema Afrianti, M.Pd.I, pada 17 April 2018)

Ketiga, bimbingan agama melalui pembelajaran rumpun PAI. Dalam proses bimbingan agama ini, guru pembimbing bekerja sama dengan guru mata pelajaran PAI, seperti guru Aqidah Akhlak, guru Al-Quran Hadits, Guru Fiqh, Guru Bahasa Arab dan guru Sejarah Kebudayaan Islam untuk memberikan wejangan pada setiap pertemuan di dalam kelas. Setiap wejangan yang di berikan disesuaikan dengan materi pembelajaran masing-masing mata pelajaran yang dipegang oleh guru mata pelajaran tersebut.

Keempat, ekstrakurikuler Baca dan Tulis Al-Quran (BTQ). Kegiatan ini laksanakan setiap satu minggu sekali di luar mata pelajaran, tetapi mempunyai jam khusus seperti mata pelajaran pada umumnya yang berdurasi 90 menit untuk setiap pertemuan, jadi secara sistematis ekstrakurikuler BTQ ini di wajibkan untuk diikuti oleh seluruh siswa dan siswi MTs Satu Atap As-Solehhiyah.

Kelima, bimbingan agama melalui teknik Clien Centred. Pada proses ini, tidak seluruh siswa/i dapat mengikutinya, akan tetapi pada proses ini lebih menekankan kepada siapa saja yang mau dan ingin mengikuti proses ini. Karena pada proses ini lebih ditekankan kepada siswa/i yang memiliki permasalahan atau mengalami guncangan batin. Karena pada proses bimbingan ini siswa/i dengan kesadaran dan atas kehendak dirinya sendiri tanpa adanya paksaan dari pihak luar. Adapun tahapan atau prosesnya diantaranya sebagai berikut: (1) Tahap awal, klien datang atas keinginan sendiri untuk menghampiri guru pembimbing, guru pembimbing menerima dengan respek tanpa menilai dan mengadili klien, klien datang dengan kondisi tidak baik, mengalami kecemasan dan mengalami guncangan, saat klien datang memiliki harapan bahwa guru pembimbing dapat membantu permasalahannya.(2) Tahap Pertengahan tahap ini, klien sedikit demi-demi sedikit mampu menceritakan permasalahan yang tengah dihadapinya. Dengan bantuan penguatan dan motivasi yang diberikan oleh guru pembimbing terdadap dirinya.

Selanjutnya, guru pembimbing memahami perasaan-perasaan yang tengah 
S, Mulyani., S. Ramdhan., D.A. Fajar.

di hadapinya. Baik itu berdasarkan perilaku negatif ataupun perasaan yang tidak menyenangkan yang dialami oleh klien. Setelah itu guru pembimbing memberikan pemahaman tentang arti kehidupan tentang permasalahan yang di hadapi klien tersebut. Sampai klien paham bahwa yang dihadapinya merupakan sebuah permasalahan yang harus di selesaikan dan sesungguhnya dirinya mampu untuk menyelesaikan seluruh permasalahan yang dihadapinya tersebut. Sehingga setelah pemberian pemahamah tersebut, klien dapat menerima dirinya sendiri sebagaimana adanya.

Tahap yang selanjutnya guru pembimbing memberikan penguatan agar klien mampu memilih pilihan yang lebih baik dan mengaktualisasikannya dalam kehidupan sehari-hari. (3) Tahap Akhir, klien merasa dirinya lega telah menceritakan segala hal yang telah dihadapinya kepada guru pembimbing, setelah dirinya merasa lega dan mampu merubah prilakunya menjadi lebih baik, klien berkesimpulan untuk mengakhiri bimbingan. Dan guru pembimbing tidak lupa untuk selalu memberikan do'a dan motivasi kepada klien agar dirinya merasa ada yang memperdulikan dirinya. (Hasil wawancara dengan Ibu Ema Afrianti, M.Pd.I, pada 17 April 2018)

Selain itu, ibu Ema menambahkan bahwa setelah proses bimbingan diatas, ibu Ema selalu memberikan feedback di setiap pertemuan baik itu pertemuan di kelas ataupun diluar kelas. Feedback itu berupa sapaan, penguatan motivasi dan kepedulian. Selain itu ketika berada di dalam kelas, selalu menyisipkan wejangan berupa penyiapan mental, jiwa dan keimanan anak dalam menghadapi masalah pribadinya

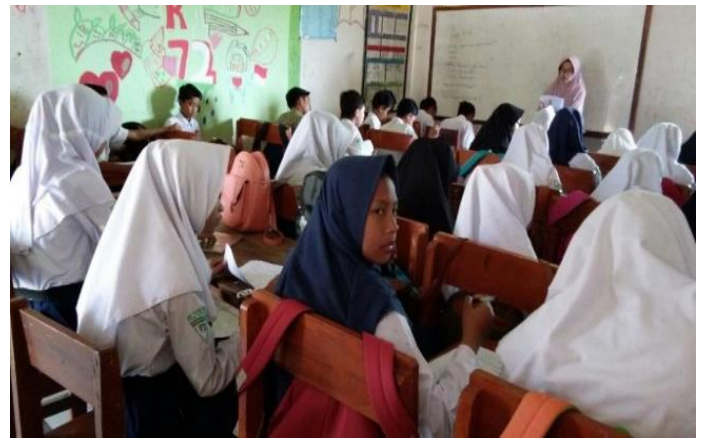

Sumber: Dokumentasi Hasil Penelitian

Gambar 1. Pemberian Arahan Mengenai Bimbingan Agama Melalui Rumpun PAI

Berdasarkan gambar 1, tujuan khusus pendidikan agama Islam, terkait dengan pengembangan rasa cinta kepada agama dan akhlak adalah : (1) 
Bimbingan Agama Melalui Teknik Clien Centred dalam Pembentukan Kepribadian Remaja memperkenalkan kepada siswa tentang aqidah, dasar-dasar dan pokok-pokok ibadah dan cara mengerjakannya, dengan cara membiasakan mereka mematuhi, menjalankan, dan menghormati aqidah dan syari'at agama. (2) menumbuhkan kesadaran pada pelajaran tentang agama dan apa yang terkandung di dalamnya tentang akhlak yang mulia. (3) menanamkan keimanan kepada Allah, pencipta alam, Malaikat, Rasul, Kitab-kitab, dan hari akhirat berdasarkan pemahaman, kesadaran dan kecintaan. (4) mengembangkan minat siswa untuk memperdalam tentang kesopanan dan pengetahuan agama, mengikuti ajaran agama dengan kerelaan dan kecintaan, menanamkan rasa cinta al- Qur an, dengan menghormati, membaca dengan baik, memahami dan mengamalkan ajarannya. (5) siswa mengetahui bahwa agama Islam adalah agama ketertiban, persaudaraan, dan kesejahteraan buat seluruh bangsa walaupun berbeda keyakinan, warna kulit, maupun tanah air.

\section{Hasil Bimbingan Agama Melalui Teknik Clien Centred}

Data tentang hasil bimbingan agama melalui teknik clien centred dalam pembentukan kepribadian remaja di MTs Satu Atap As-Solehhiyah diperoleh dari hasil observasi dan angket tertutup dengan jawabannya yang sudah tersedia dalam pertanyaan.

Penulis menggunakan angket karena dapat dibagikan secara langsung dan data hasil jawaban dapat diambil hasil jawabannya. Penelitian ini menggunakan metode pengumpulan data non tes yaitu berupa angket dengan pilihan jawaban tertutup YA/TIDAK. Data yang akan dianalisis dan diukur diperoleh langsung dari responden yang menjawab item pertanyaan. Jawaban yang diharapkan merupakan keadaan sesungguhnya dari responden sehingga item pertanyaan yang dibuat merupakan pertanyaan positif untuk dijawab sesuai dengan kondisi responden.

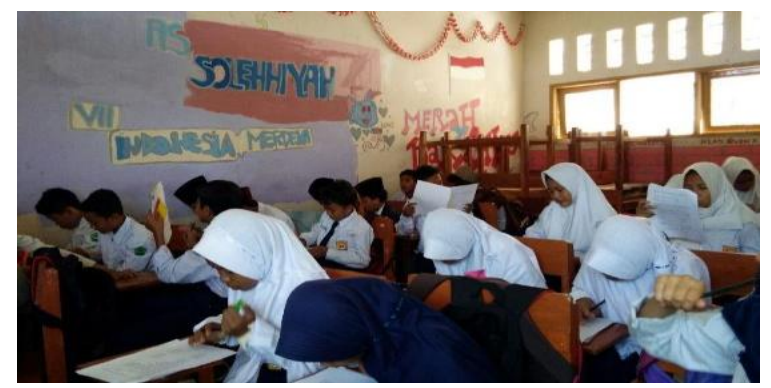

Sumber: Dokumentasi Hasil Penelitian

Gambar 2. Kegiatan Mengisi Angket

Dalam proses penelitian ini penulis menggunakan analisa data secara deskriptif untuk memaparkan hasil yang diperoleh. Dalam menghitung data-data 
S, Mulyani., S. Ramdhan., D.A. Fajar.

yang didapatkan penulis menggunakan rumus prosentase, yaitu sebagai berikut:

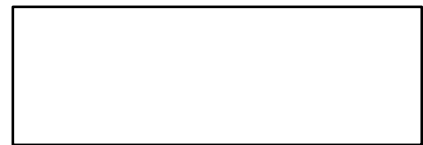

Keterangan :

F : Frekuensi (jumlah jawaban responden)

$\mathrm{N} \quad$ : Number of casses (jumlah responden)

P : : Angka Prosentase (Sudijono, 2004: 43).

Dalam mendeskripsikan Bimbingan Agama Melalui Tekni Clien Centred Dalam Pembentukan Kepribadian Remaja di kelas IX memiliki rentangan skor 01, dibuat interval dengan kriteria interaksi sosial yang ditentukan dengan cara sebagai berikut:

Data Maksimal = nilai tertinggi $\mathrm{x}$ jumlah item $=2 \times 45$

$$
=95
$$$$
=2 \times 2100 \%=100 \%
$$

Data Minimal $=$ nilai terendah $\mathrm{x}$ jumlah item $=0 \times 45=0$

$=1 / 2 \times 100 \%=50 \%$

Range $\quad=$ data maksimal - data minimal $=95-0=95$

$$
=100 \%-50 \%=50 \%
$$

Panjang Kelas Interval $=$ range $:$ panjang kelas $=95: 5=19$

Tabel 1

\section{Kategori skala Nilai}

\begin{tabular}{lll}
\hline No & Skala Nilai & Kategori \\
\hline 1. & $1 \%-25 \%$ & Sangat Kurang Baik \\
2. & $26 \%-50 \%$ & Kurang Baik \\
3. & $51 \%-75 \%$ & Baik \\
4. & $76 \%-100 \%$ & Sangat Baik \\
\hline
\end{tabular}

Sumber: Hasil penyebaran angket peneilitian

Berdasarkan tabel 1. Penyajian ini adalah hasil data dari indikator atau aspek 
Bimbingan Agama Melalui Teknik Clien Centred dalam Pembentukan Kepribadian Remaja setiap pernyataan yang dijawab oleh responden untuk mengetahui berapa besar prosentasenya setiap alternatif jawaban dari pertanyaan yang ada. Dan selanjutnya data tersebut lalu dideskripsikan dan dianalisis untuk mendapatkan suatu kesimpulan. Adapun untuk mengetahui berapa besar persentasenya tiap alternatif dan jawaban maka data tersebut diolah dalam tabel tabulasi dan dianalisis sebagai berikut:

Pertama, Teknik Client Centred: (a) Berdasarkan hasil tabulasi dan analisis diketahui bahwa dengan persentase tertinggi yaitu 91\% siswa mampu menerima keberadaan guru pembimbing, jika ditafsirkan maka dinyatakan dengan kategori sangat baik. Sehingga dapat disimpulkan bahwa siswa (klien) di MTs AsSolehhiyah mampu menerima keberadaan guru pembimbing dengan rasa peduli dan menerima nasehat yang diberikan guru pembimbing. (b) Berdasarkan hasil tabulasi dan analisa diketahui bahwa dengan persentase tertinggi yaitu 78\% siswa memiliki keselarasan dan tidak kontradiksi dengan apa yang dilakukan, jika ditafsirkan maka dinyatakan dengan kategori sangat baik.

Sehingga dapat disimpulkan bahwa siswa (klien) di MTs As-Solehhiyah memiliki keselarasan (congruence) antara apa yang dilakukan dengan yang dikatakannya. c) Berdasarkan hasil tabulasi dan analisa diketahui bahwa dengan persentase tertinggi yaitu $84 \%$ siswa mampu mengkomunikasikan sifat-sifat khasnya, jika ditafsirkan maka dinyatakan dengan kategori sangat baik. Sehingga dapat disimpulkan bahwa siswa (klien) di MTs As-Solehhiyah mampu mengkomunikasikan sifat-sifat khas agar guru pembimbing memahami apa yang tengah di rasakan oleh kliennya.

Berdasarkan penelitan yang dilakukan penulis, dapat disimpulkan dari angket tersebut bahwa persentase terbesar dari masing-masing aspek mampu membangun hubungan bimbingan dengan teknik clien centred yang baik. Hal tersebut dipertegas dengan indikator menerima, keselarasan (congruence), dan mampu mengkomunikasikan sifat-sifat khas.

Kedua, Kepribadian Remaja: (a) Berdasarkan hasil tabulasi dan analisa diketahui bahwa dengan persentase tertinggi yaitu 97\% siswa memiliki akhlak yang baik, jika ditafsirkan maka dinyatakan dengan kategori sangat baik. Sehingga dapat disimpulkan bahwa siswa (klien) di MTs As-Solehhiyah memiliki akhlak yang baik yang tercermin didalam kehidupan sehari-harinya, seperti mengucapkan salam, mencium tangan kedua orangtua, menolong sesame manusia dan lain sebagainya. (b) Berdasarkan hasil tabulasi dan analisa diketahui dengan persentase tertinggi yaitu 100\% siswa memiliki sifat rasa malu, jika ditafsirkan maka dinyatakan dengan kategori sangat baik.

Akhlak yang baik adalah pemberat timbangan orang mukmin di hari kiamat nanti Allah menyukai hak tersebut. Dan dia membenci seseorang seseorang yang 
S, Mulyani., S. Ramdhan., D.A. Fajar.

suka mengucapkan kata-kata kotor dan keji. Nabi Saw juga menyebutkan bahwa orang yang mengisi dirinya dengan akhlak yang baik akan mendapatkan kecintaan darinya (Hamid, 2006: 13-14).

Sehingga dapat disimpulkan bahwa siswa (klien) di MTs As-Solehhiyah memiliki rasa malu ketika telah melakukan kesalahan baik itu kesalahan kepada sesame manusia ataupun kepada sang penciptanya. (c) Berdasarkan hasil tabulasi dan analisa diketahui bahwa dengan persentase tertinggi yaitu 97\% siswa memiliki sifat berbakti kepada orangtua, jika ditafsirkan maka dinyatakan dengan kategori sangat baik. Sehingga dapat disimpulkan bahwa siswa (klien) di MTs AsSolehhiyah memiliki sifat berbakti kepada orangtua. (d) Berdasarkan hasil tabulasi dan analisa diketahui bahwa dengan persentase tertinggi yaitu $89 \%$ siswa memiliki sifat kelemah lembutan, jika ditafsirkan maka dinyatakan dengan kategori sangat baik.

Sehingga dapat disimpulkan bahwa siswa (klien) di MTs As-Solehhiyah memiliki sikap lemah lembut kepada sesame manusia. (e) Berdasarkan hasil tabulasi dan analisa diketahui bahwa dengan persentase tertinggi yaitu 100\% siswa memiliki sifat kejujuran, jika ditafsirkan maka dinyatakan dengan kategori sangat baik. Sehingga dapat disimpulkan bahwa siswa (klien) di MTs As-Solehhiyah memiliki sikap kejujuran, seperti jujur dalam setiap perbuatan yang telah diperbuat dan mengakui dengan jujur kesalahan yang telah diperbuat. (f) Berdasarkan hasil tabulasi dan analisa diketahui bahwa dengan persentase tertinggi yaitu 97\% siswa memiliki sifat amanah, jika ditafsirkan maka dinyatakan dengan kategori sangat baik.

Sehingga dapat disimpulkan bahwa siswa (klien) di MTs As-Solehhiyah memiliki sikap amanah, seperti menyampaikan amanah kerika diberi amah oleh siapapun. g) Berdasarkan hasil tabulasi dan analisa diketahui bahwa dengan dengan persentase tertinggi yaitu 100\% siswa memiliki sifat tawadhu' dan tidak sombong, jika ditafsirkan maka dinyatakan dengan kategori sangat baik. Sehingga dapat disimpulkan bahwa siswa (klien) di MTs As-Solehhiyah memiliki sikap tawadhu dan tidak sombong.

Berdasarkan seluruh aspek kepribadian diatas, bahwa hasil yang diperoleh merujuk pada pendapat Meity, yakni:

Kepribadian adalah sifat yang sebenarnya yang tercermin pada sikap seseorang atau suatu bangsa yang menjadi pembeda dirinya dari orang atau bangsa lain.

Dari pemaparan diatas, dengan bimbingan keagamaan melalui tekni clien centred dapat memfasilitasi siswa/i dalam membentuk kepribadian siswa. Hal tersebut diperkuat dengan penafsiran presentase positif dengan interval $76-100 \%$ 
maka kepribadian siswa di MTs As-Solehhiyah termasuk pada kategori sangat tinggi.

Dari hasil penelitian ditemukan beberapa hasil yang perlu dibahas, yaitu aktivitas siswa ketika tidak ada guru, kepribadian mereka muncul ketika guru tidak masuk kelas. Mereka menggunakan kesempatan emas ini untuk melakukan hal-hal yang bisa membuat mereka senang. Seperti membolos, ke kantin, merokok dibelakang kelas atau di kantin yang dilakukan siswa laki-laki, berdandan atau berias yang dilakukan siswa perempuan, dan masih banyak lagi kegiatan-kegiatan yang mereka lakukan.

Kepribadian siswa kelas IX di MTs Satu Atap As-Solehhiyan ini berada pada kategori sangat tinggi, kepribadiaan ini didasari oleh keinginan mendapatkan perhatian dari teman-temannya, menunjukkan eksistensi diri dan harga dirinya, cepat bosan dalam belajar, serta kesenangan pada dunia luar sekolah tepatnya tempat mereka bergaul dan meniru gaya mereka. Maka dari itu, para siswa yang berkepribadian yang tidak baik ini membutuhkan bimbingan.

Upaya yang dilakukan untuk menangani masalah kepribadian siswa, yaitu dengan bimbingan agama melalui teknik clien centred. Dengan bimbingan tersebut siswa mampu mengetahui kepribadian yang baik dan juga mampu menentukan jalan keluar dari masalah yang dialaminya. Metode yang digunakan yaitu dengan metode pembelajaran melalui rumpun PAI, shallat duha berjamaah, kultum dan shallawat serta ekstrakurikurer BTQ, yang dilaksanakan sesuai jam mata pelajaran untuk poembelajaran rumpun PAI, dan setiap hari untuk shallat duha serta kultum dan shallawat, selanjutunya setiap hari sabtuuntuk ekstrakurikurer BTQ.

Temuan tersebut menunjukan bahwa siswa kurang dalam memahami dirinya, serta kurang memahami dalam bimbingan agama terutama dari pihak keluarganya dan terlalu dibebaskannya dalam hal pergaulan oleh pihak keluarganya sehingga senantiasa dengan bebas memunculkan kepribadian mereka tiru dari pihak luar seperti lingkungan tempat mereka bergaul, sehingga muncullah kepribadian mereka sesuai dengan lingkungan tempatnya bergaul. Hal ini berarti bahwa dengan adanya penelitian mengenai bimbingan agama melalui teknik clien centred dalam pembentukan kepribadian remaja khususnya ini bisa mengalami peningkatan pada siswa yang mengalami perubahan kepribadian terutama bagi para siswa yang brokenhome yang kurang menerima perhatian dan kasih saying dari kedua orangtuanya.

\section{PENUTUP}

Berdasarkan hasil penelitian yang telah diuraikan pada bab-bab sebelumnya mengenai Bimbingan Agama Melalui Teknik Clien Centred Dalam Membentuk Kepribadian Remaja (Studi Deskriptif di Yayasan Pendidikan MTs. Satu Atap As- 
S, Mulyani., S. Ramdhan., D.A. Fajar.

Solehhiyah Kelas IX Kec. Bojongsoang Kab. Bandung), maka dapat ditarik kesimpulan sebagai berikut: pertama, Program Bimbingan Agama Melalui Teknik Clien Centred Dalam Pembentukan Kepribadian Remaja, program bimbingan keagamaan di MTs Satu Atap As-Solehhiyah disesuaikan dengan kebutuhan siswa.

Dengan demikian program yang dihasilkan oleh MTs Satu Atap AsSolehhiyah, yaitu bimbingan agama melalui shallat dhuha berjamaah, kultum dan shallawat, bimbingan agama yang diintegrasikan dengan rumpun PAI, dan ekstrakurikuler Baca dan Tulis Al-Quran (BTQ).

Kedua, Proses Bimbingan Agama Melalui Teknik Clien Centred Dalam Pembentukan Kepribadian Remaja, pelaksanaan bimbingan agama di sekolah dapat dilakukan denan cara menintegrasikan bimbingan agama dalam rumpun mata pelajaran PAI seperti mata pelajaran Aqidah akhlak, Al-quran hadits, Sejarah Kebudayaan Islam, Fiqih, dan Bahasa Arab. Selain itu bimbingan agama yang diintegrasikan dengan rumpun PAI, guru pembimbing di MTs Satu Atap AsSolehhiyah ini menyelenggarakan kegiatan bimbingan agama yang rutin dilaksanakan oleh para siswa siswinya, seperti: (a) Bimbingan agama melalui Shallat dhuha berjamaah (b) Kultum dan Shallawat (c) Ekstrakrlikuler Baca Tulis AlQur'an (BTQ). Selain itu, bimbingan agama melalui teknik clien centred lebih di fokuskan kepada setiap klien (siswa) yang memerlukan bimbingan. Adapun tahapannya sebagai berikut: (1) klien datang atas keinginan sendiri untuk menghampiri guru pembimbing (2) Klien datang dengan kondisi tidak baik, mengalami kecemasan dan mengalami guncangan (3) klien sedikit demi-demi sedikit mampu menceritakan permasalahan yang tengah dihadapinya (4) klien dapat menerima dirinya sendiri sebagaimana adanya. (5) klien merasa dirinya lega telah menceritakan segala hal yang telah dihadapinya kepada guru pembimbing, setelah dirinya merasa lega dan mampu merubah prilakunya menjadi lebih baik, klien berkesimpulan untuk mengakhiri bimbingan

Ketiga, Hasil Bimbingan Agama Melalui Teknik Clien Centred Dalam Pembentukan Kepribadian Remaja berdasarkan data responden yang didapatkan dari angket, meliputi: (a) Aspek penerimaan tergolong kategori sangat baik yakni sebesar 91\%.(b) Aspek keselarasan (congruence) tergolong kategori sangat baik yakni sebesar 78\%. c) Aspek pengkomunikasian sifat-sifat khas tergolong kategori sangat baik yakni sebesar 84\%. (d) Aspek berakhlak yang baik tergolong kategori sangat baik yakni sebesar 97\%. (e) Aspek rasa malu tergolong kategori sangat baik yakni sebesar 100\%.( f) Aspek berbakti kepada orangtua tergolong kategori sangat baik yakni sebesar 97\%. (g)Aspek kelemah lembutan tergolong kategori sangat baik yakni sebesar 89\%. (h) Aspek kejujuran tergolong kategori sangat baik yakni sebesar 100\%. (i) Aspek amanah tergolong kategori sangat baik yakni sebesar 97\%. (j) Aspek Tawadhu dan tidak sombong tergolong kategori sangat baik yakni sebesar $100 \%$. 


\section{DAFTAR PUSTAKA}

Bimbingan Agama Melalui Teknik Clien Centred dalam Pembentukan Kepribadian Remaja

Ahmad, A, dkk (2005). Psikologi Perkembangan. Jakarta: PT Rineka Cipta.

AS, Enjang, dkk (2009). Dasar-Dasar Bimbingan dan Penyuluhan Islam. Bandung: Sajjad Publishing House.

Chodijah. S. (2016). Model Bimbingan dan Konseling Komprehensif dalam Meningkatkean Akblak Mahasiswa dalam Ilmu Dakwah: Academic Journal for Homiletic Studies, $10(1), 133$.

Gerald, C. (2013) Teori dan Praktik Konseling \& Psikoterapi. Bandung: PT Refika Aditama.

Hamid, A. Ath-Thahir. (2006). Akhlak Islam Si Buah Hati: Pendidikan Akhlak Ala Nabi. Solo: Pustaka Arafah.

Helmawati (2014). Pendidikan Keluarga Teoritis dan Praktis. Bandung. PT. Remaja Rosdakarya.

Maulana, A. dan Hernisawati (2015). Konseling Religi untuk Mengembangkan Karakter Konseling dalam Ilmu Dakwah: Academic Journal for Homiletic Studies, 1(02), 55-66.

Moeleong J. Lexy (2005) Metode Penelitian Kualitatif. Bandung : Remaja Rosda Karya.

Qodratilah, M.T. (2011) Kamus Bahasa Indonesia Untuk Pelajar. Jakarta.

Rahim, F.A. (2004). Bimbingan dan Konseling Dalam Islam. Yogyakarta: UII Press.

Samsul, M.A. (2013) Bimbingan Dan Konseling Islam. Jakarta : Amzah.

Satriah, L. (2017) Panduan Bimbingan Konseling Pendidikan. Bandung: CV. Mimbar Pustaka.

Surya, M (2003). Pengantar Teori Konseling. Bandung : Pustaka Bani Quraisy. 
S, Mulyani., S. Ramdhan., D.A. Fajar. 